\title{
MANGROVES - THE COASTAL GREEN BUFFER ZONE
}

\author{
Vijaya Kumari Nunna \\ VNR Vignana Jyothi Institute of Engineering and Technology, Bachupally, Hyderabad - 500090
}

\begin{abstract}
Coastal zones are the most biologically complex and productive ecosystems. Mangroves are also termed as 'Coastal Woodlands' or 'Tidal Forests' and occur along the tropical and sub-tropical seas in bays, lagoons and estuaries region. Mangroves form a transitional complex ecosystem between the sea and land comprising of aquatic and terrestrial flora and fauna. Mangrove forests are an integral part of the coastal environment extending through out the tropics and sub-tropics of the world. Mangroves forests are of vital importance with a great socio-economic potentiality and ecological significance. Ecologically, mangroves stabilize the coastline shoreline acting as a buffer to the land mass from tidal surges, cyclonic storms and high tides. Coastal disasters are one manifestation of environmental problems and as such have ecological, social and economic dimensions. The tsunami of $26^{\text {th }}$ December 2004, which was triggered by a magnitude submarine earthquake in the Sumatra region that struck the shores of south and and south-east Asia resulted in the death or displacement of several lakhs of people. Keeping in view the unpredictable occurrence of such disasters the significant role of the natural mangrove vegetation along the coast in controlling these disasters is highlighted. The complexity and ecological importance of mangroves as a land-ocean interface ecosystem has been confirmed. Mangrove degradation is caused mainly due to commercialisation, economic and social pressures and failure to recognize the natural value of mangroves. Human anthropogenic activities and environmental stress significantly reduced the areal extent of mangrove vegetation. In the present study the depletion of mangroves along coastline of Guntur district has been estimated and evaluated. The devastating damage of life, property and natural biota due to tsunami disaster could have been minimal or prevented altogether had the mangroves along the coast been conserved and managed sustainably. Conservation of mangroves is essential for the benefit of socio-economic configurations and for the balance of complex eco-climates of the coastal ecosystem.
\end{abstract}

Keywords: Mangroves - The Coastal Green Buffer Zone

$* * *$

\section{INTRODUCTION}

Mangroves are a group of salt - tolerant species occurring in the tropical and sub-tropical inter-tidal estuarine regions, lagoons, bay and creeks spreading from the highest level of spring tide down almost to mean sea-level. Mangroves are bewildering and their peculiar bewildering adaptations to the coastal saline soil is intriguing. Under favourable conditions they can penetrate extensively along river banks forming distinctive littoral ecosystem with a majestic forest canopy.

The circumtropical global distribution of mangroves is restricted to the Indo-Pacific and the West Africa - America region. In India mangroves are distributed along the east and west coast spread over an area of 4448 sq. km. constituting nearly seven per cent of the world's mangroves. In Andhra Pradesh mangroves are confined to the south coastline which is about $1014 \mathrm{~km}$ long (FSI, 2008). The Krishna Godavari delta and the Coringa bay are the rich mangrove zones of Andhra Pradesh.

Mangrove forests are important wetlands providing environmental sustainability, ecological security and economic prosperity (Sandilyan, 2007). Mangroves stabilise the coastal shoreline and soften the impact of breaking waves. The massive tsunami on $26^{\text {th }}$ December 2004 in the Indian ocean killed more than 280,000 people and made millions homeless in eleven countries including India, Indonesia and Sri Lanka. The scale of the damage was massive and the loss to life and property almost immeasurable. Reports indicate that the devastating damage caused due to tsunami could have been minimal had the mangroves along the coast been conserved and managed sustainably (Sridhar, 2004). In this context the role of the natural mangrove vegetation as a coastal buffer zone is highlighted.

Mangroves are now an endangered species in the global scenario and have attracted considerable attention. Heavy anthropomorphic pressures and aquaculture practice caused significant loss of mangroves. In view of this the present study has been undertaken to estimate the areal extent of mangroves along the coastline of Guntur district in Andhra Pradesh. Multi temporal satellite data along with ground truth studies were conducted and ancilliary data collected to evaluate the status of mangroves.

\section{OBJECTIVES}

The primary objectives of the present study are as follows:

- Monitor the change in total area under mangroves.

- Identify the causal factors of mangrove degradation.

- Ecological impact assessment of mangrove degradation.

- Strategies for effective control of mangrove degradation.

- Approaches for sustainable management of mangroves.

\section{DESCRIPTION OF THE STUDY AREA}

Guntur district is located within the geographic co-ordinates of latitudes $15-18^{\prime}$ to $16-15^{\prime} \mathrm{N}$ and longitude of $80-55^{\prime} \mathrm{E}$. 
Total geographic area of the district is 11,377 sq.km. with a population density of 361 persons per sq.km. Normally the climate is sub - tropical with warm summers.

\section{DATABASE AND METHODOLOGY}

The primary source of data used are as follows:

- Multitemporal satellite data.

- Survey of India toposheet covering the study area.

- Ancilliary data as compiled by Directorate of Statistics and Economics.

In the present study mangrove forest area was monitored by the digital image processing technique using multi temporal sensor data. Remote sensing data from Landsat IA and IRS LISSII were used (Table - 1). Digital analysis of the data was carried out using AIX version 3.1 image processing system on a IBM host computer. The temporal data was geometrically rectified and registered through identification of ground control points and an FCC of the study area generated. Supervised classification approach using maximumlikelihood algorithm was applied to segregate the various land use / land cover classes. Statistical data of the various categories were generated. Change detection in mangrove area was estimated and evaluated.

\section{RESULTS AND DISCUSSION}

Mangrove species have specific ecological amplitude that is dictated to a major extent by the interaction of soil, water content and salinity factors. Mangroves are conspicuously present in estuaries, tidal flats and both sides of creeks along the coastline in Guntur district. In the present study the change in areal extent of mangroves was monitored over a period of three decades starting from 1973 respectively. Observations indicate that mangroves in this area are mostly degraded except at a few places due to over-exploitation. During the year 1973 the estimated area of mangroves was 63.69 sq.km. that represents 0.56 per cent of the total geographical area of Guntur district (Table - 2). Over a period of time nearly 22.0 sq. $\mathrm{km}$. of the area under mangroves is degraded. The average annual loss reported is 2.89 per cent (Table -3 ). The most obvious and immediate results of the disappearance of mangroves concerns its direct economic value. The main reason that mangroves have been constantly undervalued and poorly managed is the lack of available information about the resource, its role and the vulnerability.

Loss of mangroves has a negative impact on the socioeconomic development and adversely affects the microclimate. Mangrove vegetation slows global warming by their carbon sinks forming the 'Green Lungs' (UNDP/UNESCO, 1991). The predicted sea-level rise as a result of global warming could cause contraction of the mangrove area by inundation. The tsunami of 26th December 2004, which was triggered by a magnitude submarine earthquake in the Sumatra region that struck the shores of South and South East Asia resulted in the death and displacement of several lakhs of people. Ecologically, mangroves serve as an effective first line of defense against storms and act as a buffer zone to the land mass protecting from tidal surges, cyclonic storms and high tides. Researchers from the University of East Anglia and the Mangrove Research Centre in Hanoi, Vietnam shows that mangroves are more effective than concrete constructions at keeping out the sea and play a protective role as energy dissipaters during powerful oceanographic events. Mangroves are a means of battling stress in times of distress.

Conservation of mangroves compatible with long-run environmental objectives depends on efficient sustainable management. An accurate and up-to-date information base on the status of mangroves continually over time is an essential pre-requisite for efficient management. Observations of the present study reveal that remote sensing techniques are very effective, precise and efficient for monitoring change in areal extent of mangroves. Conservation of the vital mangrove forests is essential for the benefit of socio-economic configurations, protection of the ecosystem biodiversity and for the balance of complex ecoclimates of the unique and fragile coastal ecosystem.

\section{CONCLUSIONS}

- Mangroves are conspicuously present in estuaries, tidal flats and both sides of creeks along the coastline of Guntur district.

- Mangroves represent a highly productive ecosystem both biologically and economically. Due to lack of awareness the importance of mangroves is being neglected resulting in reckless exploitation. Due to biotic interference and environmental stress the areal extent of mangrove vegetation is gradually reducing with time along coast of Guntur district.

- Mangrove plantations provide a 'Self-Repairing System' which facilitates the stabilisation and protection of the coast during intense cyclonic conditions. The complexity and ecological importance of mangroves as a land-ocean interface ecosystem has been confirmed.

- Loss of mangroves has an adverse effect on the economic development and climatic conditions of the fragile coastal ecosystem. Documenting temporal changes to coastal zones is an essential part of understanding this unique environment. Strict guidelines is essential for conservation of mangrove ecosystems.

- Management of mangrove ecosystem requires an integrated effort of conservation, protection, development,research,ecological aspect and active participation of local inhabitants. Mangroves are to be treated as a resource to be sustained in perpetuity.

\section{REFERENCES}

[1] FSI, 2008. State of Forest Report 2005.Forest Survey of India (Ministry of Environment For Forests), Dehra dun.

[2] Sandilyan, S. 2007. Eco News, 13, 21.

[3] Sridhar, K. R., 2004. Curr. Sci., 86, 1586 - 1587.

[4] UNDP/UNESCO, 1991. The integrated multidisciplinary survey and research programme of the Ranong mangrove ecosystem. Final report 
/UNDP/UNESCO Regional project. Research and its application to the management of the mangroves of Asia and the Pacific (RAS/86/120/183.P.)

Table 1. Details of temporal satellite remote sensing data:

\begin{tabular}{|l|l|l|l|l|}
\hline $\begin{array}{l}\text { Sl. } \\
\text { No. }\end{array}$ & Sensor & Path/Row & $\begin{array}{l}\text { Data } \\
\text { Type }\end{array}$ & Band \\
\hline 1 & Landsat - 2 MSS & $152 / 49$ & Digital & 457 \\
\hline 2 & Landsat - 5 MSS & $142 / 49$ & Digital & 237 \\
\hline 3 & IRS - IA LISS - I & $23 / 57$ & Digital & 234 \\
\hline 4 & IRS - IB LISS - II & $23 / 57$ & Digital & 234 \\
\hline
\end{tabular}

Table 2. Total area estimation of mangrove forest using remote sensing techniques, Guntur district, Andhra Pradesh.

\begin{tabular}{|l|l|llll|}
\hline $\begin{array}{l}\text { Sl. } \\
\text { No. }\end{array}$ & Parameter & \multicolumn{4}{|l|}{ Year of Assessment } \\
\hline 1 & $\begin{array}{l}\text { Mangrove area } \\
\text { (sq.km) }\end{array}$ & 1973 & 1985 & 1992 & 1997 \\
\hline 2 & $\begin{array}{l}\text { Percent mangrove } \\
\text { area }\end{array}$ & 63.6 & 41.59 & 26.51 & 22.63 \\
\hline 3 & $\begin{array}{l}\text { To total geographical } \\
\text { area }\end{array}$ & 0.56 & 0.36 & 0.23 & 0.19 \\
\hline
\end{tabular}

Table 3. Temporal monitoring of mangrove forest area using remote sensing techniques, Guntur district, Andhra Pradesh.

\begin{tabular}{|l|l|l|}
\hline $\begin{array}{l}\text { Sl. } \\
\text { No. }\end{array}$ & $\begin{array}{l}\text { Decrease in mangrove } \\
\text { area (sq. Km.) }\end{array}$ & $\begin{array}{l}\text { Average annual } \\
\text { decrease (sq. Km.) }\end{array}$ \\
\hline 1 & 22.09 & 1.84 \\
\hline 2 & 15.08 & 3.07 \\
\hline 3 & 03.87 & 0.77 \\
\hline
\end{tabular}

